\title{
IRON ORE WASTE CLASSIFICATION ACCORDING TO UNEP GUIDELINES (CASE STUDY: GOLGOHAR MINING AND INDUSTRIAL COMPLEX IN SIRJAN, IRAN)
}

\author{
SHAHBA, S. ${ }^{1}-$ ARJMANDI, R. $.^{1 *}-$ MONAVARY, M. ${ }^{2}-$ GHODUSI, J. ${ }^{3}$ \\ ${ }^{I}$ Department of Environmental Management, Science and Research Branch, Islamic Azad \\ University, Tehran, Iran \\ (e-mail: s.shahba62@gmail.com; tel: +98-9-131-795-882) \\ ${ }^{2}$ Department of Environmental Science, Science and Research Branch, Islamic Azad University, \\ Tehran, Iran \\ (e-mail: monavarism@yahoo.com; tel:+98-9-121-772-380) \\ ${ }^{3}$ Soil Conservation and Watershed Management Research Institute, Tehran, Iran \\ (e-mail: jamal_go@yahoo.com; tel: +98-9-121-864-292) \\ *Corresponding author \\ e-mail: rezaarjmandi@yahoo.com; tel: +98-9-123-274-632 \\ (Received $19^{\text {th }}$ Oct 2016; accepted $20^{\text {th }}$ Jul 2017)
}

\begin{abstract}
Population growth has prompted governments to encourage industrial development in order to improve the welfare of their citizens. This process increases the deposition of human and industrial waste in the environment. The consequences of this have produced a serious need to implement appropriate management strategies in order to reduce and control the effect of the accumulation of such waste. The current study was undertaken to compile information about the status of iron ore waste produced by the Golgohar Mining and Industrial Complex in Sirjan, Iran, in 2015 by observation, field visits, interviews with officials and experts of the unit and the use of questionnaires and technical documentation. The industrial waste was classified using UNEP guidelines and guidelines for proper management of waste have been presented. The results of data analysis regarding the quantity and quality of mining and industrial waste of Golgohar Mining and Industrial Complex showed that about 24 million tons of solid industrial waste is produced annually. A large percentage comprises hazardous waste according to UNEP classifications and include rock and soil tailings from processing, dry and wet tailings. These are classified into group $\mathrm{E}$ as high volume and low-risk waste and in group A as mining waste containing heavy metals. The presence of heavy metals increases the importance of controlling and managing this waste.
\end{abstract}

Keywords: hazardous waste, solid waste, heavy metals, United Nations Environment Programme

\section{Introduction}

Since the development of mining industry, mining exploitation activities have enhanced solid wastes production and induced increasingly grievous destruction on the eco-environment. Waste rock, tailings and other solid waste are the largest industrial solid waste generated in the process of exploitation of mineral resources (Lu and Cai, 2012). Mining activity leaves behind a great variety of waste materials which often contain high concentrations of toxic elements (András et al., 2012).There exist a large number of issues such as stockpiled tailings resources, environment, safety and land, etc. Since there is a technology gap between different periods of smelt, a great deal of valuable resources is being retained in the tailings, and if these tailings resources cannot be integrated in the recycling process, it will cause a huge waste on the enviroment (Yang et al., 2011). Mining wastes are referred to as those wastes produced during 
mining operations in the form of returned load, mining overburden or tailings (BHP Billiton Mitsubishi Alliance, 2009). In general, mine tailings are mechanically, physically, chemically and biologically deficient (Vega et al., 2006), characterized by instability and limited cohesion, with low contents of nutrients and organic matter and high levels of heavy metals (He et al., 2005).Opencast mining activities have a serious environmental impact on soils and water streams, generating millions of tons of mine tailings (Bhattacharya et al., 2006). With the rapid development of iron and steel industry, the proportion of iron ore tailings in industrial solid waste is rapidly increasing. According to incomplete statistics, the total amount of cumulative iron tailings is nearly $2 * 10^{9}$ tons (Wang et al., 2009).

On the other hand, mining and smelting of metal ores have increased the occurrence and spread of heavy metals contamination in the soil, especially open pit mining which produces million tons of mine tailings, which have serious environmental impact on soil and water flow (Bhattacharya et al., 2006). The contamination of soil by heavy metals is one of the major environmental problems facing many countries around the world, considering their almost indefinite persistence in the environment and the danger they pose (Ding et al., 2013). Therefore tailings are environmentally problematic in that they are natural (crushed) particles impregnated with the chemicals used in mining. Tailings which contain iron sulfide also contain heavy metals such as antimony, arsenic, beryllium, cadmium, lead, nickel, selenium, silver and zinc. These tailings can cause the environment to produce acidic drainage in the presence of oxygen and water (Balvardi, 2010). Among other environmental concerns in relation to tailings from the mining of iron ore is the presence of fibrous forms of mineral silicates belonging to the serpentine and amphibole groups of rock-forming minerals, including asbestos in tailings (Kesler, 1994).Incidents of poor waste management practice are amongst the most conspicuous features of the global minerals industry. Tailings spills, dam failures, seepage, unrehabilitated sites and cases of direct discharge into water ways can result in severe and long-term environmental and social consequences (Van Zyl, 1993; ICME and UNEP, 1998; Hart, 2007; Franks, 2007; Spitz and Trudinger, 2009; Fourie, 2009).

Mining and industrial waste, if not properly controlled, will create problems for industrial units. They occupy space, can cause injury to employees, create odors and attract insects and stray animals. Dumping of debris on surrounding land can cause complaints and enforcement by regulatory bodies. Such materials are usually produced in large quantities, which will increase the cost of storage, handling and disposal; however, it can also make recycling economically justified (Habibinejad, 2000). Studies in China, India, Russia and Spain have shown the widespread use of iron mine tailings to be economically feasible and, in many cases, profitable. It reduces the volume of waste and, under optimal management, the regional environmental situation can be improved. Use of the proposed operation and management strategies can also compensate for or reduce the cost of production (Zhang et al., 2006).

In India approximately $10-15 \%$ of the iron ore mined is unutilized, even now, and is discarded as waste/tailings due to lack of cost effective technology in extracting low grade ores. Because of this huge piles of mine wastes are found in and around mine areas (Ahmari and Zhang, 2012). However, some of these waste materials possess potential characteristics, which can be tapped for various uses (Hussain, 1995; Water, 2001; Menezes and D‘Souza, 2004; Kumar, 1998). Hammond (1998) in his study critically reviewed the usage of mining waste as building material. He identified many mining wastes as concrete aggregates and pigments for paints. Das et al. (2000) 
developed new techniques for converting iron ore tailings into value added products such as ceramic floor and wall tiles for building application. It was proved that such tiles have high strength and hardness compared to conventional tiles. The investigation also revealed other benefits like energy economy and lower production costs, which is also strengthened by the study carried out by Reddy (2004) and Zhang et al. (2006).

Mining waste is environmentally hazardous because of the large volume produced and the presence of chemical reagents. Heavy metals can be found in some types of mining waste, indicating the need for proper management of its disposal.

The costs related to the control and management of hazardous waste are higher than for other waste and its mismanagement can incur heavy fines. It is very important for a manufacturing unit to operate economically (Habibinejad, 2000); thus, all waste management plans must consider the economic aspects as of equal importance with the environmental issue.

\section{Literature Review}

Decision-making on waste infrastructures is difficult because waste management is a complex, politically loaded and emotionally charged issue that is neither well structured, nor well understood. While sustainability is the ultimate goal of the EU environmental policy, there is no commonly accepted approach for its realization (Verhoef et al., 2006).

The first step in waste management is to identify and classify waste according to given standards and laws. The first laws and regulations pertaining to hazardous waste management were implemented by European common market countries in 1980. The United Nations Environment Programme (UNEP) established the principles of environmental management of hazardous waste in 1987. The Basel Convention was adopted by 35 participating countries in Switzerland in 1989 to control trans boundary movement of hazardous waste. At present, 105 countries, including Iran, have joined the treaty since September 1992 (Binavapoure, 2010). The waste law was passed in Iran in 2004. The law consists of 23 articles and waste has been classified into five categories, including those of hazardous(or special) waste. Hazardous waste refers toall waste that requires special handing due to the presence of at least one of dangerous property (toxicity, pathogenicity, possibly explosive or ignitable and corrosive). Similar to medical waste and some general waste, industrial, mining and agricultural waste that requires special management is classified as special or hazardous (Office of Legal and Parliamentary Affairs, 2004).

Different methods have been used for the classification of waste, including those based on how waste is produced, its detrimental effects, the degree of risk and the physical state (Abdoli et al., 2010). Each method of identification and classification of hazardous waste has advantages and disadvantages. The use of lists and directories is a relatively simple method for the identification of hazardous waste. The most important directories and classifications include the US Environmental Protection Agency (USEPA) quad list, UNEP classification and Basel Convention classification (Abdoli et al., 2010). In Iran, classification of industrial waste is often done based on these three classifications.

Sabzalipour et al. (2007) studied the feasibility of industrial waste minimization in Bandar Imam Petrochemical Complex and first identified the waste, its quantity and quality and then classified it according to UNEP guidelines (Sabzalipour et al., 2007). 
Namdari and Turkian (2010), studied management of waste and chemicals used in Asaluyeh Pardis Petrochemical Company and classified them according to the Resource Conservation and Recovery Act (RCRA) and Basel Convention (Namdari and Torkian, 2010). The present study was undertaken to identify all industrial waste from the Golgohar Mining and Industrial Complex in Sirjan, Iran. Beside waste identification, the quality and quantity was determined and the type of waste was classified according to UNEP guidelines.

\section{Materials and Methods}

\section{Study area}

Golgohar Mining and Industrial Complex $\left(29^{\circ} 7^{\prime} 5^{\prime \prime} \mathrm{N}\right.$ and $\left.55^{\circ} 19^{\prime} 5^{\prime \prime} \mathrm{E}\right)$ (Figure 1) is located $55 \mathrm{~km}$ South West of Sirjan city in Kerman province, south of Iran. According to Iran's National Census in 2006, the population of Sirjan is 167,014 , scattered in 40,605 families. The study area is located at an altitude of $1730 \mathrm{~m}$ above the sea level; it is situated in a depression between the southern Zagros Mountains to the west and the Kuh-e Bidkhan massif to the east (Sirjan county, 2015). Golgohar Mining and Industrial Complex is the main source of revenue for the city. It meets $30 \%$ of the needs of steel fatories in Iran. Based on the method of De martonne, drought index was 39/6, and based on this classification, the climate of the study area is dry (Kousha Madan Consulting company, 2014).

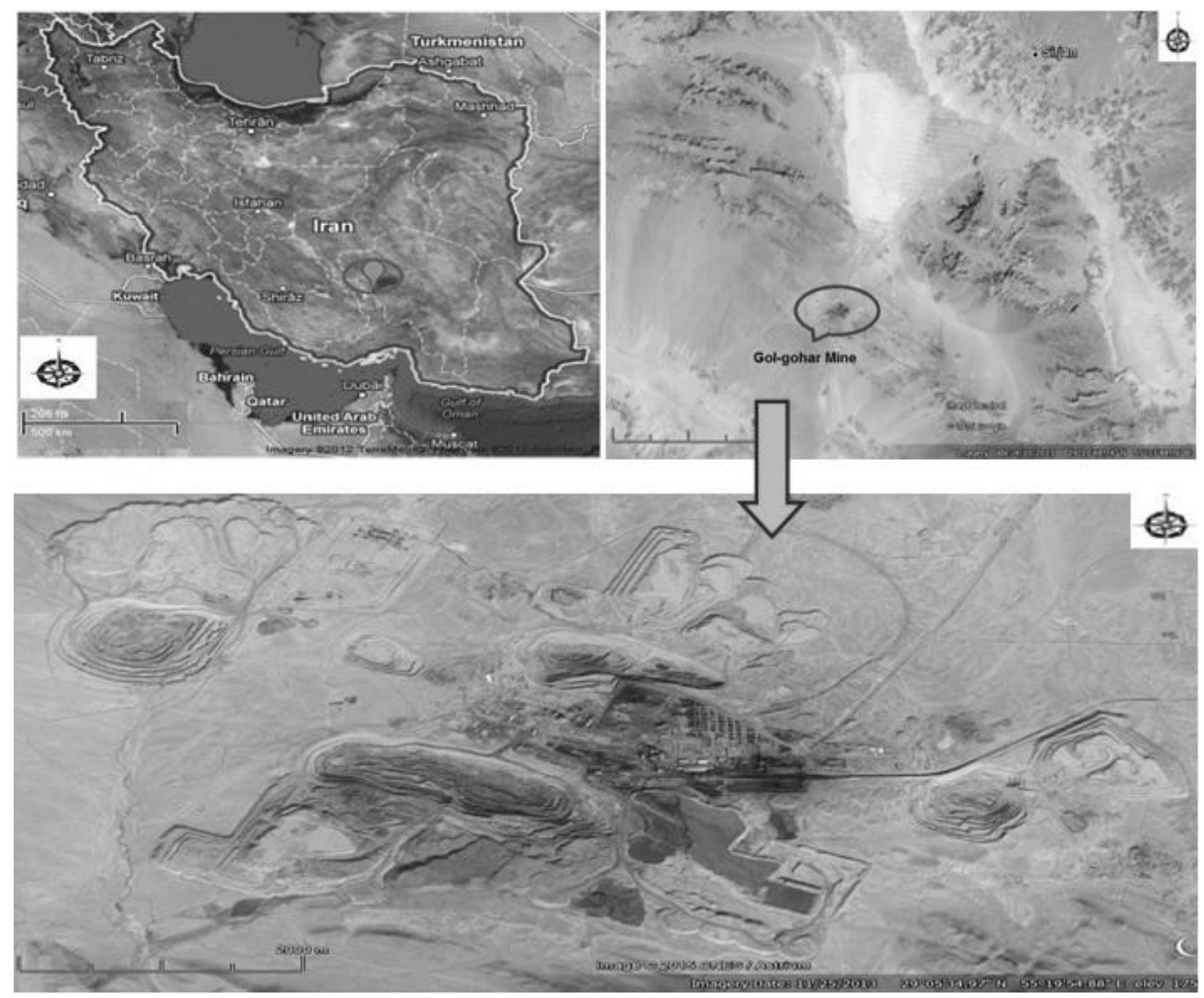

Figure 1. Study area in Sirjan County, Kerman Province, Iran 
Golgohar Mining and Industrial Complex comprises four plants, three of which are involved with ore beneficiation and concentration. These are the magnetite processing, hematite recovery and desulfurization and polycom processing plants. The fourth plant is the pelletizing plant, which is responsible for the agglomeration of concentrates produced by the other three plants. Each plant produces different types of waste according to their process and the raw material and additives used.

\section{Methods}

To carry out this research, field visits and interviews with the managers and owners of industry were carried out and a questionnaire containing 29 questions was developed and completed. To obtain accurate and real date, information was also obtained from annual reports of the environmental unit and technical documents from the plants and MSDS instructions and executive program reports on waste management were disclosed. This neutralized the subjectivity of the manager responses, which can be a prevalent problem on similar research efforts.

Ultimately, UNEP guidelines were used in the pluralization of the information obtained and classification of waste. Recommendations and management strategies were then presented using the results. The method used in this study consisted of four parts:

- Part I: Library research;

- Part II: Field visits;

- Part III: Questionnaire preparation;

- Part IV: Classification of waste in accordance with UNEP guidelines and provision of appropriate management strategies.

In the first part, the method applied involved gathering the most recent statistics and background information using the resources available in libraries, scientific and research centers, Golgohar Mining and Industrial Complex and internet searches in the fields of mining, environment and waste management. In the second part, in order to become more familiar with the complex's performance, field visits and interviews were conducted with managers of industry, then producer points and sources of industrial waste were identified through field visits. In the third part, the quantity, nature and mode of industrial waste were identified through the questionnaires.

In the fourth part, after analysis of the collected data, an attempt was made to classify the waste based on the type produced and according to the UNEP guidelines. Thereafter, appropriate strategies for waste management were provided. This study was based on the information obtained from the exploitation and processing units of Golgohar Mining and Industrial Complex and focused on studying the quality and quantity of industrial waste and classifying it according to international standards.

\section{Classification of waste}

From the perspective of UNEP, hazardous waste is defined as waste materials that is either solid, sludge, liquid or gas in the tank, except for radioactive materials, which have chemical activity, toxicity, explosive and corrosive properties or other characteristics, and has been shown to pose detrimental effect on human health or the environment either by itself or when mixed with other materials (LaGregaet al., 2001).

UNEP classification is based on the type of waste, industry or process involved in the production of hazardous waste. One advantage of this classification is that it can largely 
make the environmental administrators and managers aware of the types of industry and processes that must be controlled. In this classification, the type of waste material, industry or process and the abbreviated titles of the groups are presented in table form. The waste was divided into six groups (Abdoli et al., 2010) as shown in Table 1 according to UNEP guidelines.

Table 1. Classification of waste according to UNEP

\begin{tabular}{|c|c|c|c|c|c|c|c|c|c|c|c|}
\hline \multicolumn{2}{|c|}{$\begin{array}{c}\text { Group } \\
\text { A } \\
\end{array}$} & \begin{tabular}{|c|}
$\begin{array}{c}\text { Nature of the } \\
\text { waste }\end{array}$ \\
\end{tabular} & \begin{tabular}{|c|}
$\begin{array}{c}\text { Group } \\
\text { B }\end{array}$ \\
\end{tabular} & \multicolumn{2}{|c|}{\begin{tabular}{|c|}
$\begin{array}{c}\text { Group } \\
\text { C }\end{array}$ \\
\end{tabular}} & $\begin{array}{c}\text { Nature of the } \\
\text { waste }\end{array}$ & \multicolumn{2}{|c|}{ GroupGroup } & \multicolumn{2}{|c|}{\begin{tabular}{|c|} 
Group \\
F \\
\end{tabular}} & $\begin{array}{c}\text { Nature of the } \\
\text { waste }\end{array}$ \\
\hline \multirow{6}{*}{ 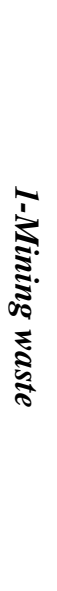 } & $1-1$ & Acids and alkali & \multirow{6}{*}{ 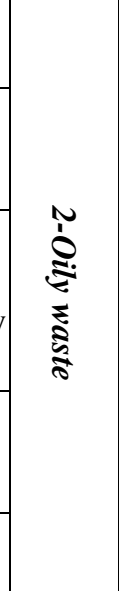 } & \multirow{6}{*}{ 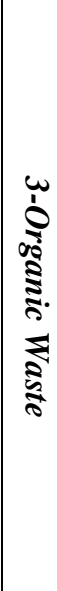 } & $3-1$ & $\begin{array}{c}\text { Used halogenated } \\
\text { solvents }\end{array}$ & \multirow{6}{*}{ 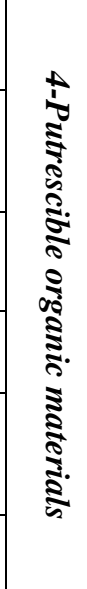 } & \multirow{6}{*}{ 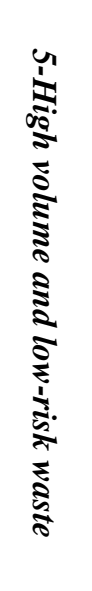 } & \multirow{6}{*}{ 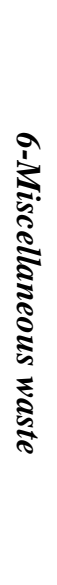 } & \multirow[b]{2}{*}{$6-1$} & \multirow[b]{2}{*}{ Infectious waste } \\
\hline & $1-2$ & $\begin{array}{c}\text { Wastes } \\
\text { containing } \\
\text { Cyanide } \\
\end{array}$ & & & $3-2$ & $\begin{array}{c}\text { Used non- } \\
\text { halogenated } \\
\text { solvents }\end{array}$ & & & & & \\
\hline & \multirow{2}{*}{$1-3$} & $\begin{array}{c}\text { Dissolved and } \\
\text { sludges }\end{array}$ & & & $3-3$ & $\begin{array}{c}\text { Wastes containing } \\
\text { PCB }\end{array}$ & & & & \multirow{2}{*}{$6-2$} & \multirow{2}{*}{$\begin{array}{c}\text { Laboratory } \\
\text { Waste }\end{array}$} \\
\hline & & $\begin{array}{c}\text { containing heavy } \\
\text { metals }\end{array}$ & & & $3-4$ & $\begin{array}{l}\text { paints and resins } \\
\text { waste }\end{array}$ & & & & & \\
\hline & $1-4$ & $\begin{array}{c}\text { Wastes } \\
\text { containing } \\
\text { Asbestos }\end{array}$ & & & $3-5$ & Pesticide waste & & & & \multirow[t]{2}{*}{$6-3$} & \multirow{2}{*}{ Explosive waste } \\
\hline & $1-5$ & $\begin{array}{c}\text { uncertain Solid } \\
\text { remains }\end{array}$ & & & $3-6$ & $\begin{array}{c}\text { Chemical organic } \\
\text { materials }\end{array}$ & & & & & \\
\hline
\end{tabular}

Mining/smelting is one of the main sources of heavy metal pollution in the environment, and the tailings generally contain higher concentration of heavy metals. Therefore, several researches have been conducted on different metal mining tails and surroundings to determine the behavior of the heavy metals (Rodrguez et al., 2009; Romero et al., 2007; Moncur et al., 2005; Lowry et al., 2004).

The findings indicates that mine tailings can be classified using the UNEP method of classification based on the presence of heavy metals, as well as its high volume.

\section{Results}

The information obtained from the questionnaire regarding the qualitative and quantitative assessment of waste from Golgohar, interviews with managers and experts and a review of reports and technical documents helped determine the type of waste produced in the mining region. It comprised tailings of rock and soil from ore extraction, dry and wet tailings from magnetic separation, effluent from flotation cells containing tailings and reagents used in flotation and oil and grease used on equipment, in addition to worn-out components and equipment.

Industrial waste of different types can be classified according to different criteria. Some researchers have classified industrial waste based on their generation source, while others have classified them based on their specifications. Waste can also be classified according to its internal components. What is important for classification is to facilitate the identification and management of waste. Industrial waste can be classified as either hazardous or non-hazardous. 
The three types of waste identified were analyzed for seven elements (heavy metals) with respect to the degree of danger (degree of hazard of each type of waste and the most significantly hazardous by type). The seven elements were chosen using the toxicity characteristic leaching procedure (TCLP) approved by the USEPA to determine the hazardous waste by testing for 40 elements in and the composition of waste. Seven elements that were measurable by Iranian laboratory methods were selected of the 40 TCLP elements and tested to determine the hazardous nature of each type of tailing and its degree of danger. Table 2 shows that results for three types of tailings for the seven elements: silver $(\mathrm{Ag})$, arsenic $(\mathrm{As})$, cadmium $(\mathrm{Cd})$, chromium $(\mathrm{Cr})$, lead $(\mathrm{Pb})$, vanadium (V) and zinc (Zn) was done (Table 2).

Table 2. The amount of heavy metals in each type of tailing

\begin{tabular}{|l|c|c|c|c|c|c|c|}
\hline \multicolumn{1}{|c|}{ Tailing type } & $\begin{array}{c}\mathrm{Ag} \\
(\mathrm{ppm})\end{array}$ & $\begin{array}{c}\mathrm{As} \\
(\mathrm{ppm})\end{array}$ & $\begin{array}{c}\mathrm{Cd} \\
(\mathrm{ppm})\end{array}$ & $\begin{array}{c}\mathrm{Cr} \\
(\mathrm{ppm})\end{array}$ & $\begin{array}{c}\mathrm{Pb} \\
(\mathrm{ppm})\end{array}$ & $\begin{array}{c}\mathrm{V} \\
(\mathrm{ppm})\end{array}$ & $\begin{array}{c}\mathrm{Zn} \\
(\mathrm{ppm})\end{array}$ \\
\hline Worthless tailings rock and soil & $<1$ & 5 & $<1$ & 41.81 & 32.36 & 82 & 56.72 \\
\hline Dry tailings & $<1$ & 9.2 & $<1$ & 27.2 & 14.6 & 63.8 & 39.2 \\
\hline Wet tailings & $<1$ & 6.5 & $<1$ & 33.66 & 32.75 & 206.75 & 69.08 \\
\hline
\end{tabular}

The results indicate that the presence of heavy metals, especially $\mathrm{Cr}, \mathrm{Pb}, \mathrm{V}$ and $\mathrm{Zn}$ were above normal. In addition to being classified as hazardous according to the UNEP, their large volume require environmental measures to optimize the management of these types of waste.

The wet tailings had the highest amount of $\mathrm{Pb}$ and $\mathrm{Zn}$ and a significantly higher amount of V. Dry tailings contained the highest amount of As and rock and soil tailings contained the highest amount of $\mathrm{Cr}$.

\section{Hazardous waste of Golgohar Mining and Industrial Complex}

- Worthless tailings rock and soilfor processing are classified as group E "High volume and low-risk waste" according to UNEP's classification.

- Dry tailings are classified as group A "Mining waste containing heavy metals" according to UNEP's classification.

- Wet tailings are classified as group A "Mining waste containing heavy metals" according to UNEP's classification.

- Used oils, including compressors and mills oil,etc are classified as group B "Oily waste" according to UNEP's classification.

- Burned grease is classified as group B "Oily waste" according to UNEP's classification.

- Used activated carbon is classified as group C "Organic Waste" according to UNEP's classification.

Any type of waste with at least one dangerous property can be called hazardous waste. These include chemical activity, toxicity, pathogenicity, explosion or ignition creation, corrosion and any others that are risky or likely to cause harm to human health or the environment, either by itself or when mixed with other materials. 


\section{Non-hazardous waste of Golgohar Mining and Industrial Complex}

Any type of waste that is not classified into groups A, B, C, D, E and F is known as non-hazardous waste. Accordingly, non-hazardous waste would include used activated alumina, molecularsieves, worn balls and rods from mills, steel liners from mills, rubber liners and parts of mills, abrasive parts of pumps, filter and cleaning cloth, wire and cotton strips, plastic sectors, lifter bars, impact bars, shell plates, wooden cartons, boxes and pallets, great bars (metal parts of the pallet floor) and steel pallets.

\section{Classification of hazardous waste according to their characteristics}

Waste is called hazardous if it possesses corrosive, explosive or ignitable or toxic properties or shows chemical activity. Given the importance of this issue, after identifying the waste in the study area, it was characterized and classified. The results are shown in Table 3.

Table 3. Classification of GolGohar Mining and Industrial Complex's wastes based on UNEP's method

\begin{tabular}{|c|c|c|c|c|c|c|c|c|c|c|c|}
\hline \multirow{2}{*}{$\begin{array}{l}\text { Order } \\
\text { index }\end{array}$} & \multirow[t]{2}{*}{ Waste } & \multicolumn{5}{|c|}{$\begin{array}{c}\text { Hazardous } \\
\text { waste's } \\
\text { classification }\end{array}$} & \multicolumn{4}{|c|}{ Specifications } & \multirow{2}{*}{$\begin{array}{c}\text { Non- } \\
\text { hazardous } \\
\text { waste }\end{array}$} \\
\hline & & $A$ & $B \mid C$ & $C D$ & $E$ & $\boldsymbol{I}$ & Corrosive & \begin{tabular}{|l|} 
Ignition \\
creation
\end{tabular} & \begin{tabular}{|c|} 
High \\
affinity
\end{tabular} & Toxicity & \\
\hline 1 & Worthless tailings rock and soil & & & & * & & & & & * & \\
\hline 2 & Dry tailings & $*$ & & & & & & & & * & \\
\hline 3 & Wet tailings & $*$ & & & & & & & & * & \\
\hline 4 & Used oils & & $*$ & & & & & $*$ & & & \\
\hline 5 & Burned grease & & * & & & & & * & & & \\
\hline 6 & Used activated carbon & & & * & & & & * & & & \\
\hline 7 & Used activated alumina & & & & & & & & & & * \\
\hline 8 & Molecularsive & & & & & & & & & & $*$ \\
\hline 9 & Worn balls and rods of mills & & & & & & & & & & * \\
\hline 10 & Steel liners of mills & & & & & & & & & & * \\
\hline 11 & Rubber liners and parts of mills & & & & & & & & & & * \\
\hline 12 & Abrasion parts of pumps & & & & & & & & & & $*$ \\
\hline 13 & Filter's cloth and cleaning cloth & & & & & & & & & & * \\
\hline 14 & Wire strips & & & & & & & & & & $*$ \\
\hline 15 & Cotton strips & & & & & & & & & & * \\
\hline 16 & Plastic sectors & & & & & & & & & & * \\
\hline
\end{tabular}




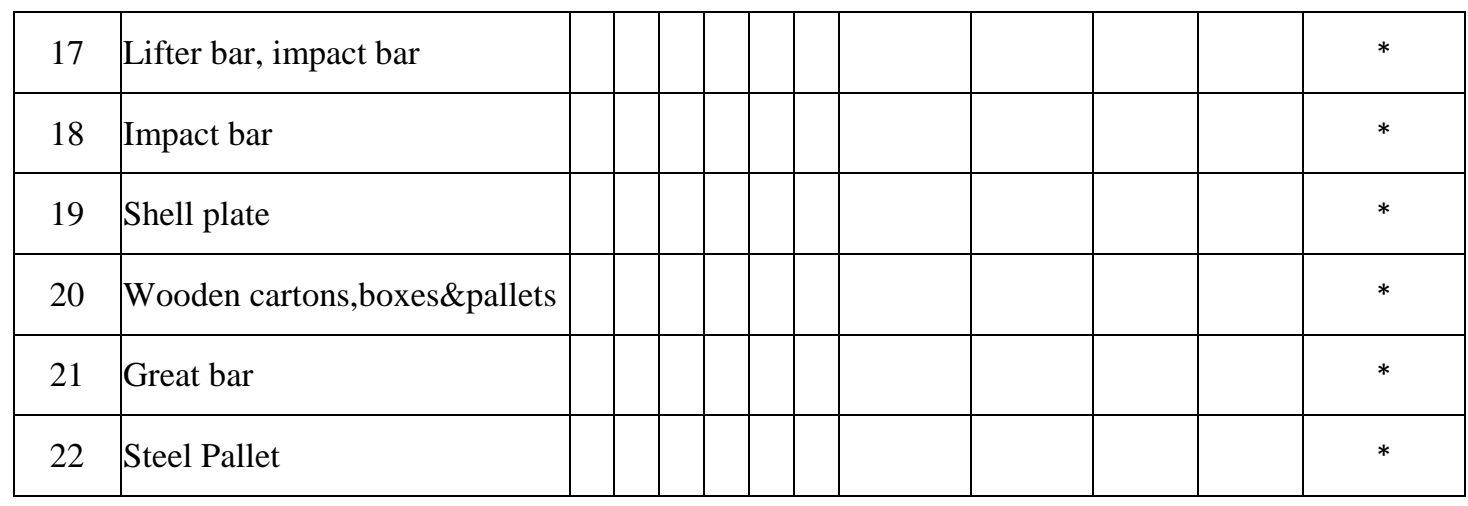

A: Mining waste

B: Oily waste

C: Organic Waste

D: Putrescible organic materials

E: High volume and low-risk waste

F: Miscellaneous waste

Analysis of the data shows that, of the 22 types of waste identified at Golgohar Mining and Industrial Complex, six were hazardous because they possessed at least one dangerous UNEP property. These were rock and soil tailings, dry tailings, wet tailings, used oil and grease and used activated carbon. Another 14 showed no hazardous characteristics and were considered to be non-hazardous waste. Despite the small number of types of waste classified as environmentally hazardous, the percentage of each was higher than the percentage of non-hazardous waste because of their high volume. This means that of the 24,461,753 tons of industrial waste produced at in 2015, 24,452,753 tons were environmentally hazardous and 9,000 tons were non-hazardous according to UNEP standards. In other words, more than $99 \%$ of the industrial waste in the study area was considered to be hazardous and less than $1 \%$ was considered to be non-hazardous (Figure 2). Note that of the 24,452,753 tons of hazardous waste, about $19,768,236$ tons were rock and soil tailings, which were considered to be high volume and low-risk waste according to the UNEP classification (Figure 3).

\section{Industrial wastes of Gol Gohar mining and industrial complexes}

\section{Non-hazardous waste $\quad$ Hazardous waste}

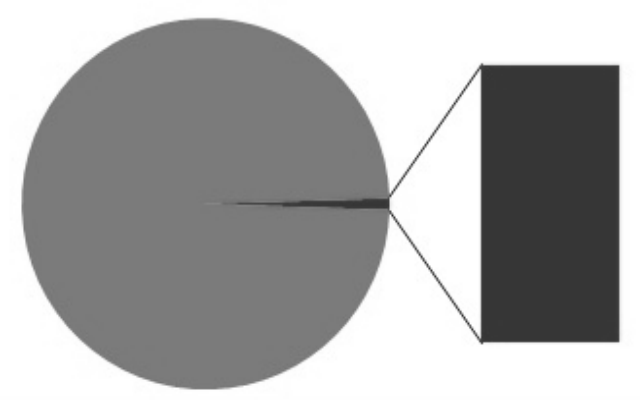

Figure 2. Percentage hazardous and non-hazardous waste in GolGohar Mining and Industrial Complex according to UNEP's classification in 2015 


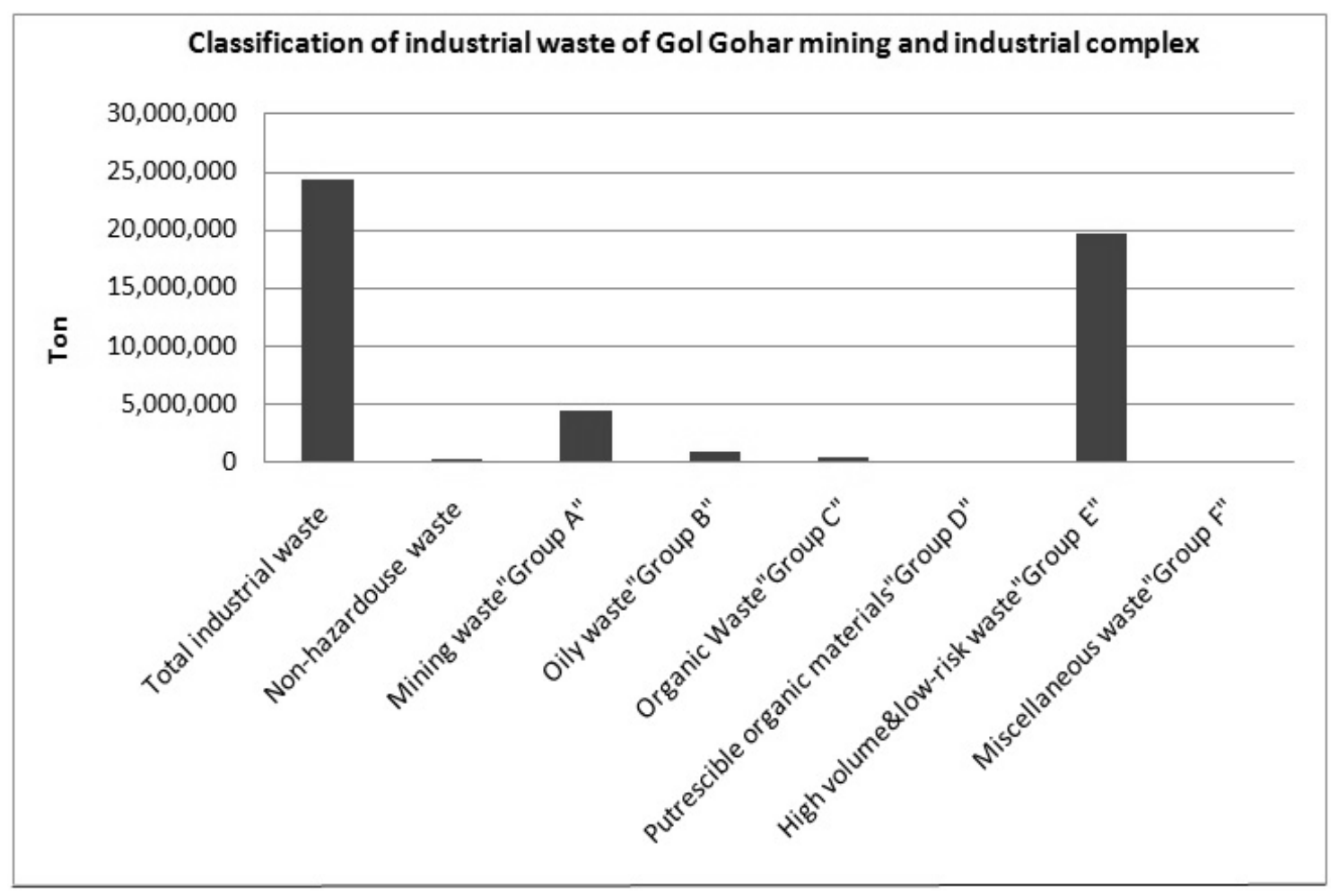

Figure 3. Classification of all industrial wastes in GolGohar Mining and Industrial Complex according to the UNEP's classification in 2015

It should be noted that from the total of $24,452,753$ tons of hazardous waste, about 19,768,236 tons included tailing rock and soil, which were considered as High volume and low-risk waste according to UNEP's classification (Figure 3).

\section{Discussion}

Soil and water are important environmental resources which can be contaminated and seriously threatened by improper disposal of industrial waste. It has been suggested that water and soil be protected as a serious investment with the implementation of waste management. Unfortunately, despite the appropriate legal bases in Iran such as the Third and Fourth Development Plans and other environmental laws, gaps and shortcomings in the implementation of industrial waste management has been observed. Practical suggestions for improving the execution of industrial waste management in Golgohar Mining and Industrial Complex have been suggested by the analysis and the results of previous studies in this region.

\section{Reduce waste at the source of production}

A basic principle of waste management is that waste reduction should begin at the origin and continue through all stages of production. It is evident that reducing waste at the source is fundamental and more efficient than at other stages. In many cases, the effective use of resources, a decrease in the consumption of raw materials, recycling, and the reuse of waste are accompanied by significant social and economic benefits, such as reduced cost of production and decreased pollution and disposal costs. 
One way of reducing the amount of industrial waste is to change the process. In some cases, manufacturing may contain defects which create waste. Such waste can be reduced by the removal of the defects and modification of the process. A change in the process may be done by modifying equipment, process automation and operation planning (such as regulation of temperature, pressure and amount of raw materials). For example, the volume of tailings in most cases can be reduced when lines and equipment are controlled in order to ensure optimal performance. A defect at any stage of manufacturing, such as crushing, magnetic separation, flotation, filtering, screening and handling can be controlled by continuous control of the lines to reduce tailing production. Rock and soil tailings, however, including waste containing iron (at a lower grade than currently economically viable due to lack of access to advanced technology) and other elements which have economic value, such as copper and vanadium, need further investigation to ascertain their potential use. The volume and amount of waste, together with its danger and toxicity can be reduced through the practice of tailings.

\section{Recycle waste}

In the waste management hierarchy, after waste reduction at the source, follows recycling and reuse of waste. It may be possible to use waste again in the same process after recycling at the production unit or could be given to other units for recycling and then used for final processes. If a unit can recycle its waste, the volume of the waste produced will decrease and savings will increase in disposal operations and, most importantly, in their collection and transportation. This is an important step toward protecting the environment.

Because industrial waste is produced in separated form and in high volumes in the manufacturing and industrial units, its recycling become easier and more efficient than municipal solid waste. In the study area, a certain percentage of waste is recycled; thus, it was recommended that recycling of waste be followed with thorough assessment of existing waste production and determination of the potential of industrial waste recycling. Dust captured by the electrostatic precipitator and wet scrubber sludge are taken back into the production process, recyclable metal parts are collected and sold, and used oil is collected and transferred after filtering and treatment. It is evident that all non-hazardous waste, except activated alumina and molecularsieves, are recyclable and can be sold to recycling plants for plastic, rubber, metal and paper. In addition to compensating for part of the purchasing expense of these materials, this can help prepare the raw materials for another industrial unit. This addresses many of the problems and costs associated with landfills and disposal of these materials, which is the responsibility of the manufacturer.

The last alternative for waste recycling is their use for thermal energy. At present, much waste is burned in cement and asphalt kilns or consumed as auxiliary fuel in a fossil fuel furnace. Used rubber and tires and used oil and grease are used in large industrial complexes after output standards have been strongly observed. Used vehicle tires (trucks and lorries) and used oil and grease are common in the study area; their volume means they can be sold to cement and asphalt kilns. This will decrease the volume of waste and also compensate for part of production expenses. Energy recovery of waste is preferred to its disposal.

The chemical composition of the tailings shows that they contain elements such as silica oxide, aluminum oxide, calcium oxide, magnesium oxide, titanium oxide and iron oxide that can be considered for making cement blocks, bricks, ceramics and glass. 
Rock and soil tailings can be used as road infrastructure and in mine rehabilitation programs after harvest and final discharge (Table 4).

Table 4. Chemical characteristics of tailing

\begin{tabular}{|l|c|c|c|c|c|c|c|}
\hline & $\begin{array}{c}\text { Silica } \\
\text { Oxide } \\
\mathbf{S i O}_{2}(\mathbf{\%})\end{array}$ & $\begin{array}{c}\text { Aluminium } \\
\text { Oxide } \\
\mathbf{A l}_{2} \mathbf{O}_{3}(\boldsymbol{\%})\end{array}$ & $\begin{array}{c}\text { Calcium } \\
\text { Oxide } \\
(\mathbf{C a O})(\boldsymbol{\%})\end{array}$ & $\begin{array}{c}\text { Magnesium } \\
\text { Oxide } \\
(\mathbf{M g O})(\boldsymbol{\%})\end{array}$ & $\begin{array}{c}\text { Titanium } \\
\text { Oxide } \\
\mathbf{T i O 2}(\%)\end{array}$ & $\begin{array}{c}\text { Iron } \\
\text { Oxide } \\
\mathbf{F e O}(\boldsymbol{\%})\end{array}$ & $\begin{array}{c}\text { Iron } \\
\mathbf{F e} \\
(\boldsymbol{\%})\end{array}$ \\
\hline Dry tailings & 32.48 & 7.75 & 6.26 & 12.53 & 0.48 & 3.42 & 18.24 \\
\hline Wet tailings & 29.52 & 6.34 & 7.43 & 15.40 & 0.34 & 3.87 & 36.66 \\
\hline
\end{tabular}

The use of advanced technologies for further concentration can be added to the agenda. Because iron ore concentrationis done by using its magnetic property, iron extraction can be increased by increasing the strength of the magnetic separators. A survey has shown that processing plants in the Golgohar complex can extract $68 \%$ of the iron from ore. Increasing the magnetic strength of the separators can allow extraction of a higher percentage of iron. This would reduce the volume of waste and increase production at processing plants, making it more economical.

Because mining tailings contain precious and rare metals in low grades, extraction of these metals can be arranged. In addition to the economic benefits, this can lead to the removal of the risks of heavy metals, which primarily threaten the quality of water and soil and, secondarily, the health of the community.

Mining tailings are potentially suitable for a variety of uses. The aggregation and physical properties of iron mine tailings advocate their use as a primary material in the manufacture of cement and concrete. Mine tailing recycling for use in other industries saves energy and resources and has economic benefits. It also reduces the volume of accumulated mining waste and can reduce problems associated with the accumulation and disposal of mining tailings.

Acknowledgements. The authors would like to acknowledge the Specialized support of Sirjan's Gol Gohar mining and industrial Co. The authors appreciate the anonymous reviewers for their useful comments to improve quality of the study.

\section{REFERENCES}

[1] Abdoli, M.A., Jalili Ghazizade, M., Samieefard, R. (2010): Hazardous waste management. - University of Tehran's publication, Tehran, $358 \mathrm{pp}$.

[2] Ahmari, S., Zhang, L. (2012): Production of ecofriendly bricks from copper mine tailings through geopolymerization. - Construction and Building Materials 29:323-331.

[3] András, P., Turisová, I., Dirner, V., Krnác, J., Dirner, V., Voleková-Lalinskád, B., Buccher, G., Jelen, S. (2012): Hazards of Heavy Metal Contamination at L'ubietová CuDeposit (Slovakia) - Procedia Environmental Sciences 14: 3 - 21.

[4] Balvardi, M. (2010): Geochemical model and mass balance of causing toxic heavy metals in rock, ore, soil, sediment, water and tailings' geochemical cycle of Sirjan's Gol Gohar iron ore, Master thesis. - Environmental Geology, Bahonar University, Kerman, Iran. 
[5] Bhattacharya, A., Routh, J., Jacks, G., Bhattacharya, P., Mörth, M. (2006): Environmental assessment of abandoned mine tailings in Adak, Va"sterbotten district (northern Sweden) - Appl Geochem. 21:1760-1780. Environmental Impact Statement Report, (based on 2007 data), Mineral Waste, section 5, Report No. 42626158.

[7] Binavapoure, M. (2010): Site selection for landfill of Booali and Lalejin Industrial park in Hamadan province, Master thesis. - Environment Health, University of Medical Sciences, Tehran, Iran.

[8] Das, S. K., Sanja, K., Ramachandra Rao, P. (2000): Exploitation of Iron Ore Tailing for the Development of Ceramic Tiles. - Waste Management 20(8): 725-729.

[9] Ding, Z., Wang, Q., Hu, X. (2013): Extraction of heavy metals from water-stable soil aggregates using EDTA. - International Symposium on Environmental Science and Technology (2013 ISEST), Procedia Environmental Sciences. 18: 679 - 685. (available online at www.sciencedirect.com)

[10] Fourie, A. (2009): Preventing catastrophic failures and mitigating environmental impacts of tailings storage facilities. - Procedia Earth and Planetary Science 1:1067-1071.

[11] Franks, D.M. (2007): Consuming landscapes: towards a political ecology of resource appropriation. - Ph.D thesis, Griffith School of the Environment, Centre for Governance and Public Policy, Griffith University.

[12] Habibinejad, M. (2000): Industrial Waste Management Practical Guide. - Avam publication, Tehran, Iran.

[13] Hammond, A. A. (1998): Mining and Quarrying Wastes: A Critical Review. Engineering Geaology 25(1): 17-31.

[14] Hart, B. (2007): Improving the sustainability of mining waste management. - Ph.D Thesis, Department of Chemical and Biomolecular Engineering, University of Melbourne.

[15] He, Z.L., Yanga, X.E., Stoffellab, P.J. (2005): Trace elements in agroecosystems and impacts on the environment. - Rev J Trace Elem Med Biol. 19:125-140.

[16] Hussain, A. (1995): Deforestation and Mining Industry. - The Indian Mining \& Engineering Journal 47(3):29-30.

[17] ICME and UNEP (1998). Case Studies on Tailings Management. International Council on Metals and the Environment and United Nations Environment Programme , 58p.

[18] Iran's office of the Legal and Parliamentary Affairs, Environmental laws and regulations (2004). Vol.1, Department of Environmental Protection's publication, Iran, 950 pp.

[19] Kesler, S. E. (1994): Mineral resources, economics and the environment. - Macmillan Co., New York, 400 pp.

[20] Kousha Madan Consulting company. (2014). Mine Affairs management of Sirjan's Gol Gohar mining and industrial complex.5.

[21] Kumar, S. N. N. (1998): Utilization of Iron Ore Waste Tailings in the Manufacture of Roofing Tiles and Bricks - Preliminary Studies, in Proceedings of National Workshop on Cost Effective Building Technology, pp. 32-39.

[22] LaGrega, M.D., Buckingham, P.L., Evans, J.C. (2001): Hazardous Waste Management. 2nd edition. McGraw- Hill Science, United state, 1202 pp.

[23] Lowry, G.V., Shaw, S., Kim, C.S., Rytuba, J.J., Brown, G.E. (2004): Macroscopic and microscopic observations of particle-facilitated mercury transport from New Idria and Sulphur Bank mercury mine tailings. - Environ Sci Technol. 38: 5101-5111.

[24] Lu, Z., Cai, M. (2012): Disposal methods on solid wastes from mines in transition from open-pit to underground mining, Procedia Environmental Sciences. vol.16, 715 - 721.

[25] Menezes, R. R., D‘Souza, M. (2004): Use of Granite Sawing Wastes in the Production of Ceramic Bricks and Tiles. - Journal of Concrete Sciences 23(3): 12-34.

[26] Moncur, M.C., Ptacek, C.J., Blowes, D.W., Jambor, J.L. (2005): Release, transport and attenuation of metals from an old tailings impoundmentm. - Appl Geochem. 20:639-659. 
[27] Namdari, A., Torkian, F. (2010). Classification and management of waste and chemicals used in Pardis Petrochemical Company of Asaluyeh under RCRA and the Basel Convention. - Journal of Environmental Science and Technology 47(4): 119-128.

[28] Reddy, V. (2004): Sustainable Building Technologies. - Current Science 87(7): 899-906.

[29] Rodrguez, L., Ruiz, E., Alonso-Azcaratec, J., Rincon, J. (2009): Heavy metal distribution and chemical speciation in tailings and soils around a $\mathrm{Pb}-\mathrm{Zn}$ mine in Spain. - J Environ Manag. 90:1106-1116.

[30] Romero, F.M., Armienta, M.A., Gonzalez-Hernandez, J.L. (2007): Solid-phase control on the mobility of potentially toxic elements in an abandoned lead/zinc mine tailings impoundment; Taxco, Mexico. - Appl Geochem. 22:109-127.

[31] Sabzalipour, S., Jafarzade, N., Monavari, M. (2007): Feasibility of industrial waste minimization in Bandar Imam Petrochemical Complex. - Journal of Environmental Science and Technology 33(2): 55-64.

[32] Sirjan county. Wikipedia, The free Encyclopedia; [cited February 2013]; Available from: http://en.wikipedia.org/wiki/Sirjan.

[33] Spitz, K., Trudinger, J. (2009): Mining and the Environment: From Ore to Metal. - CRC Press, 891p.

[34] Van Zyl, D. (1993): Mine waste disposal. - In: Daniel, D.E. (Ed.) Geotechnical Practice for Waste Disposal. - Chapman \& Hall, London, Chapter 12; pp. 269-286.

[35] Vega, F.A., Covelo, E.F., Andrade Marcet, M.L.P. (2006): Relationships between heavy metals content and soil properties in mine soils. - Anal ChemActa 524: 141-150.

[36] Verhoef, E.V., van Houwelingen, J.A., Dijkema, G.P.J., Reuter, M.A. (2006): Industrial ecology and waste infrastructure development: A roadmap for the Dutch waste management syste. - Technological Forecasting \& Social Change (73):302-315.

[37] Wang, X-L., Ren, R.-C., Liu, Y. (2009): Application of DTA in preparation of glassceramic made by iron tailings. - The 6th International Conference on Mining Science \& Technology, Procedia Earth and Planetary Science. 1:750-753. (available online at www.sciencedirect.com).

[38] Water, O. (2001): Eco-materials for Developing Countries. - PhD Thesis, TU Delft, Netherlands.

[39] Yang, Y., Sun, W., Li, S. (2011): Tailings dam stability analysis of the process of recovery, First International Symposium on Mine Safety Science and Engineering. Procedia Engineering 26:1782 - 1787. (available online at www.sciencedirect.com).

[40] Zhang, S., Xue, X., Liu, X., Duan, P., Yang, H., Jiang, T., Wang, D., Liu, R., (2006): Current Situation and Comprehensive Utilization of Iron Ore Tailing Resources. - Journal of Mining Science 42(4): 105-110. 